-Sinha YN, Selby FW, Lewis UJ, Vanderlaan WP. A homologous radioimmunoassay for human prolactin. $J$ Clin Endocrinol Metab 1973;36:509-16.

" Glick SM, Roth J. Yalow RS. Berson SA. Immunoassay of human growth hormone in plasma. Nature 1963;199: 784-7.

- Abraham G. Handbook of radioimmunoassay. New York: Dekker, 1977: 591-652.

* Greulich WW, Pyle SI. Radiographic atlas of skeletal development of the hand and wrist. 2nd ed. Stanford: Stanford University Press, 1959.

9 Surana RB. Conen PE. Partial trisomy 4 resulting from a 4/18 reciprocal translocation. Ann Genet (Paris) 1972;15 $191-4$.

11 Dutrillaux B, Laurent C, Forabosco A. et al. La trisomie 4q partielle. A propos de trois observations. Ann Genet (Paris) 1975;18:21-7.

11 de la Chapelle A, Koivisto M, Schröder J. Segregating reciprocal $(4 ; 21)(\mathrm{q} 21 ; \mathrm{q} 21)$ translocation with proposita trisomic for parts of $4 \mathrm{q}$ and 21 . J Med Genet 1973;10:384-9.

12. Schwingshackl A, Ganner E. Partielle B trisomei bei cri du chat syndrom. Padiatr Padol 1973;8:362 -71.

1:3 Fonatsch C. Faltz SD. Partial trisomy $4 \mathrm{q}$ and partial monosomy $18 \mathrm{q}$ as consequence of a paternal balanced translocation $\mathrm{t}(4 \mathrm{q} ; 18 \mathrm{q}$ - ). Humangenetik 1974;25:227-33.

14 Schrott HG, Sakaguchi S, Francke U, Luzzatti L. Fialkow PJ. Translocation, $t(4 q-; 13 q-)$ in three generations resulting in partial trisomy of the long arm of chromosome 4 in the fourth generation. $J$ Med Genet $1974 ; 11: 201-5$.

15 Sparkes RS, Francke U. Syndrome of mental retardation and multiple congenital defects associated with partial trisomy of the long arm of chromosome 4 due to an inherited 20q translocation. Am J Hum Genet 1973: 25:73A.

16 Vogel W. Siebers JW, Gunkel J, et al. Phenotypic variation in partial trisomy 4q. Humangenetik 1975;28:103-12.

1- Baccichetti C. Tenconi R, Anglani F, Zacchello F. Trisomy $4 \mathrm{q} 32 \rightarrow 4 \mathrm{qter}$ due to a maternal $4 / 21$ translocation. J Med Genet 1975;12:425-7.

18 Cervenka J. Djavadi GR. Gorlin RJ. Partial trisomy 4q syndrome. Case report and review. Hum Genet 1976: 34:1-7.

19 Biederman B, Bowen P. Partial trisomy $4 \mathrm{q}$ due to familial 2/4 translocation. Hum Genet 1976;33:147-53.

20 Issa M. Potter AM, Blank CE. Multiple congenital defects associated with trisomy for long arm of No 4. J Med Genet 1976:13:326-9.

2 Nielsen J, Rasmussen K, Lassen LB, Christiansen F. A family with a high risk of segregation for an autosomal unbalanced reciprocal translocation. Hum Genet 1976;32:343-8.

2:2 Yunis E, Giraldo R, Egel H, Ramirez E. Partial trisomy 4q. Ann Genet (Paris) 1977;20:243-8.

2:3 Canki N, Debevec M, Rainer S, Rethoré M. Trisomie $4 \mathrm{q} 26 \rightarrow 4 \mathrm{qter}$ par translocation $\mathrm{t}(4 ; 18)(\mathrm{q} 26 ; \mathrm{q} 23)$ mat. Ann Genet (Paris) 1977;20:195-8.

24 McDermott A, Poulding R, Crecry D. Cri-du-chat syndrome in a child with a $46, X X, \operatorname{der}(5) t(4 ; 5)(q 32 ; p 14)$ pat karyotype. Hum Genet 1977;39:109-12.

25 Stella M, Bonfante A, Ronconi G, Rossi G. Partial trisomy $4 \mathrm{q}$ : two cases with a familial translocation $\mathrm{t}(4 ; 18)$ (q27;q23). Hum Genet 1979;47:245-51.

26 Bonfante A. Stella M, Rossi G. Partial trisomy 4q: two cases resulting from a familial translocation $t(4 ; 18)$ (q27;p11). Hum Genet 1979;52:85-90.

27 Grumbach MM, Conte FA. Disorder of sex differentiation. In: Williams RH, ed. Textbook of endocrinology. 6th ed. Philadelphia: Saunders, 1981.

28 Rabinowitz D. Some endocrine and metabolic aspects of obesity. Annu Rev Med 1970;21:241-58.

29 Flier JS, Khan CR, Roth J, Bar RS. Antibodies that impair insulin receptor binding in an unusual diabetic syndrome with severe insulin resistance. Science 1975; 190:63-5.

30 Khan CR, Megyesi K, Bar RS, Eastman RC, Flier JF. Receptors for peptide hormones: new insights into the pathophysiology of disease states in man. Ann Intern Med 1977;86:205-19.

31 Khan CR, Flier JS, Bar RS, et al. The syndromes of insulin resistance and acanthosis nigricans. Insulinreceptor disorders in man. $N$ Engl J Med 1976;294:739-45.

:32 Kobayashi M, Olefsky JM, Elders J, et al. Insulin resistance due to a defect distal to the insulin receptor: demonstration in a patient with leprechaunism. Proc Natl Acad Sci USA 1978;75:3469-73.

Correspondence and requests for reprints to $\operatorname{Dr} \mathrm{MA}$ Angulo, Department of Pediatrics, Nassau County Medical Center, 2201 Hempstead Turnpike, East Meadow, NY 11554, USA.

\title{
Deletion of the short arm of chromosome 3: a case report with necropsy findings
}

\author{
DEBRA BENECK*, MARK J SUHRLAND +, RICHARD DICKER +, \\ M ALBA GRECO+, AND SANDRA R WOLMAN* \\ Departments of Pathology ${ }_{+}^{*}$ and Pediatrics ${ }_{+}^{+}$, New York University Medical Center, New York, \\ NY 10016, USA.
}

SUMMARY A male infant with partial deletion of the short arm of chromosome 3 is described. The features this patient shares with six previously reported cases include microcephaly, dolichocephaly, micrognathia, epicanthic folds,

Received for publication 25 October 1983.

Accepted for publication 28 October 1983. ptosis, low set or malformed ears, postaxial polydactyly, and growth or mental retardation or both. In addition, visceral anomalies not previously reported in association with this chromosomal abnormality are described. These characteristics may constitute a recognisable clinical syndrome. 
Deletion of the short arm of chromosome $3(3 \mathrm{p}-)$ was first reported by Verjaal and DeNef in $1978 .{ }^{1}$ Since then, five more children with this unusual anomaly have been described. All of the previously reported cases have survived infancy; the oldest patients were 18 years old at the times of publication. ${ }^{2} 3$ The patient described below died at the age of 3 months of aspiration pneumonia, probably owing to micrognathia and relative macroglossia. External features, radiological characteristics, and gross and microscopic findings at necropsy are presented below, with comparison with the previously reported cases.

\section{Case report}

The patient was born on 21.8.81 after 34 weeks' gestation. Apgar scores were 8 and 9 at 1 and 5 minutes respectively. Labour was induced by pitocin after spontaneous rupture of the membranes. $\mathrm{He}$ was the male child of a healthy 26 year old woman and healthy 25 year old man. The pregnancy was unremarkable; the mother denied $x$-ray exposure or use of alcohol, drugs, or tobacco. Previous pregnancies had resulted in a male sib now aged $4 \frac{1}{2}$ years and healthy, an elective abortion, and a miscarriage at 8 weeks' gestation. There was no family history of congenital anomalies.

Physical examination at birth revealed a weight of $1660 \mathrm{~g}$, a length of $41 \mathrm{~cm}$, and a head circumference of $29.5 \mathrm{~cm}$. Based on a maturity rating system, he was judged to be appropriate for 34 weeks' gestation. The head was dolichocephalic. Transverse folds were noted below each eye extending from the epicanthus to the midcheek, and the upper eyelids had prominent creases. The eyes had an antimongoloid slant and epicanthic inversion. The nasal bridge was low, and the nares anteverted, and the philtrum widened and flattened. The ears were low set and there was a preauricular pit on the left side (fig 1). The lips were thin and the palate high and arched. There was micrognathia, the neck appeared short, and the right sternocleidomastoid muscle seemed to insert abnormally. There was a small dimple over the sacrum and the foreskin was short. The upper extremities showed bilateral clinodactyly, long thumbs bilaterally with abnormal insertions, and a $0.5 \mathrm{~cm}$ accessory digit on the fifth finger of the left hand. Both heels were prominent and both fifth toes were long.

The patient was transferred to the special care nursery for low birth weight infants and given intravenous hydration. The bilirubin rose to a maximum of $7.5 \mathrm{mg} / \mathrm{dl}$ on the third day of life and the patient was treated with phototherapy. The supernumerary finger was tied off and removed. At

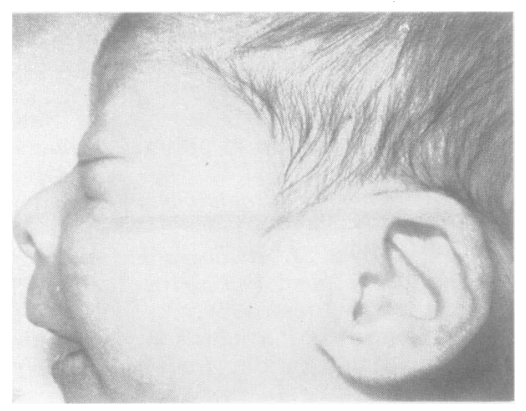

FIG 1 Facial appearance of patient showing ptosis, micrognathia, low set ear, preauricular pit, and microcephaly.

two weeks of age he began having feeding problems, consisting of inspiratory stridor with sucking and cyanosis after feedings. Chest and lateral neck $x$-rays were normal. An oesophagram showed no abnormalities. The stridor on sucking was attributed to relative macroglossia. The patient gained weight poorly and had several apnoeic episodes associated with sucking. At the age of 2 months a surgical procedure was performed which fixed the base of the tongue to the floor of the mouth in order to improve the airway. Repeated respiratory arrests occurred despite surgery. The patient developed aspiration pneumonia and was treated with ampicillin and gentamicin. He was found in asystole and could not be resuscitated on 30.11 .81 .

\section{CYTOGENETIC STUDIES}

Periperal blood lymphocytes stimulated with phytohaemagglutin were cultured for 72 hours to provide metaphase cells. Cells were analysed by $G, Q$, and $R$ banding. The segment from $3 \mathrm{p} 25$ to 3 pter was missing consistently from one of the chromosome 3 pair. Since terminal portions of chromosomes are relatively pale with $\mathrm{G}$ banding, $\mathrm{R}$ banding was done to confirm the deletion (fig 2). Both parents had a normal karyotype.

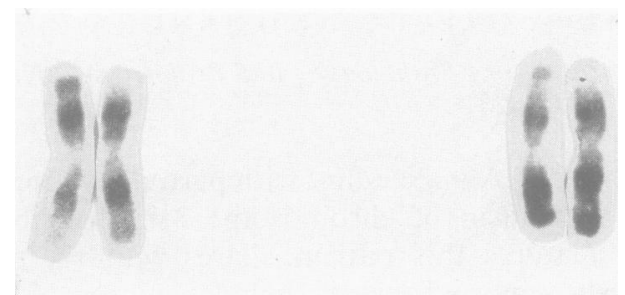

FIG 2 Partial karyotype of proband. The uppermost dark band is clearly missing from the chromosome 3 on the right in both pairs. 


\section{NECROPSY FINDINGS}

Examination of the infant at necropsy revealed the external anomalies described above. $X$-ray examin-

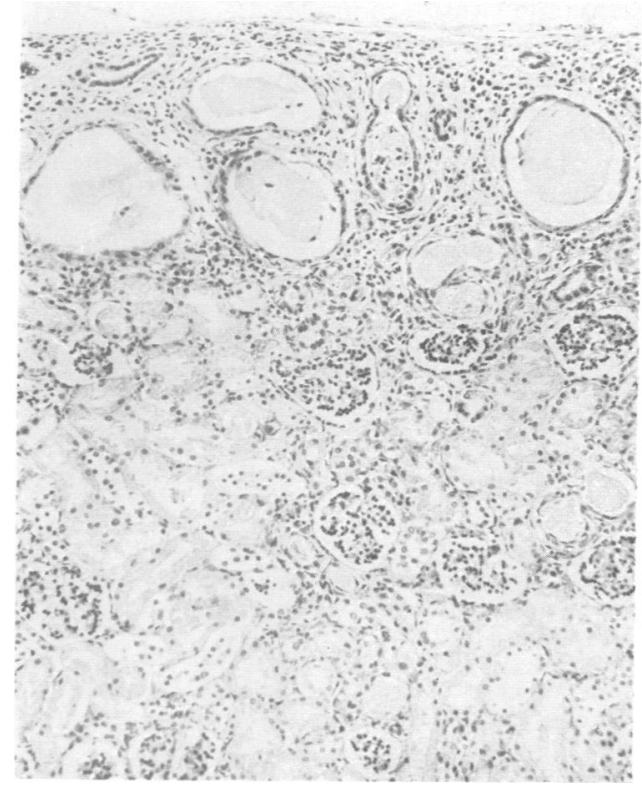

FIG 3 Left kidney showing cortical cysts formed by dilated tubules surrounded by increased interstitial connective tissue. (Haematoxylin and eosin.

Original magnification $\times 100$.) ation after death showed hypoplasia of the clavicles, mandible, and pubis, a widened pubic symphysis, and retardation of bone age. The cranial sutures were sclerotic and accessory bones were present within the sagittal suture. Internal examination revealed abdominal organ situs to be normal, but the right mesocolon was absent. The organ weights were less than expected for the body weight. The kidneys were of normal shape with the usual fetal lobulation, but showed multiple tiny cysts. Both ureters and the bladder were hypoplastic but patent, as was the urethra. There was a butterfly adrenal gland. Microscopically, cystic dilation of tubules and glomeruli with increased interstitial connective tissue was seen in both kidneys. The cysts were present mainly in the cortex with some dilated tubules in the medulla (fig 3). The brain showed evidence of acute ischaemic change, but was otherwise unremarkable. Other necropsy findings included focal organising pneumonia, fatty change, congestion, and haemosiderosis of the liver, and marked stress involution of the thymus gland. The placenta was not examined.

\section{Discussion}

Deletion of the short arm of chromosome 3 has been reported only six times previously. ${ }^{1-5}$ However, the present case is the only one in which necropsy material is available, since the other patients who have been reported with this anomaly have all

TABLE Comparison of features of previously reported cases and present case.

\begin{tabular}{|c|c|c|c|c|c|c|}
\hline & $\begin{array}{l}\text { Verjaal and } \\
\text { De Nef } 1 \\
(2470 \mathrm{~g} \text { male })\end{array}$ & $\begin{array}{l}\text { Gonzales } \\
\text { et al } 2 \\
\text { (1915 g female })\end{array}$ & $\begin{array}{l}\text { Merrild } \\
\text { et al }{ }^{3} \\
(2800 \mathrm{~g} \text { male })\end{array}$ & $\begin{array}{l}\text { Garcia } \\
\text { Sagredo et al } 4 \\
(2 \text { females })\end{array}$ & $\begin{array}{l}\text { Higginbottom } \\
\text { et al } 5 \\
(2552 \mathrm{~g} \text { male })\end{array}$ & $\begin{array}{l}\text { Present case } \\
(1660 \mathrm{~g} \text { male })\end{array}$ \\
\hline \multicolumn{7}{|l|}{ Craniofacial } \\
\hline Dolichocephaly & + & & + & & & + \\
\hline Microcephaly & + & + & & ++ & + & + \\
\hline Micrognathia & $\div$ & - & - & & + & + \\
\hline Epicanthic folds & $\therefore$ & + & + & & + & + \\
\hline Low nasal bridge & & + & & & - & + \\
\hline Anteverted nostrils & & & & & - & + \\
\hline Long philtrum & & & & & + & + \\
\hline Thin lips & + & & & & + & + \\
\hline Preauricular pit & + & & & & & + \\
\hline Low set ears & & + & + & & & + \\
\hline Malformed ears & + & + & & ++ & & + \\
\hline High arched palate & +- & & & & & + \\
\hline Ptosis & $\div$ & + & + & $+t$ & + & + \\
\hline Synophrys & & + & + & & & \\
\hline \multicolumn{7}{|l|}{ Musculoskeletal } \\
\hline Clinodactyly & + & & & & & + \\
\hline Abnormal insertion of thumbs & & & & & & + \\
\hline Postaxial polydactyly & + & & + & & + & + \\
\hline Sacral dimple & & + & & & + & + \\
\hline Prominent heels & + & & + & & & + \\
\hline Hypotonia & & & + & & & \\
\hline \multicolumn{7}{|l|}{ Other } \\
\hline Growth retardation & $\perp$ & +- & + & ++ & + & + \\
\hline Mental retardation & + & $\therefore$ & + & $\therefore \div$ & + & Not assessable \\
\hline Congenital heart disease & ?(murmur) & & + & & ?(murmur) & - \\
\hline
\end{tabular}


survived. A comparison of features observed in all seven patients is reviewed below (table). The most prominent features in all, or nearly all, cases include microcephaly (6/7) dolichocephaly (3/7), micrognathia $(5 / 7)$, epicanthic folds $(5 / 7)$, low set or malformed ears (6/7), and ptosis (7/7). Visceral anomalies seen in the current case were renal cysts with hypoplasia of the bladder and ureters, fused adrenal glands, and anomalous mesenteric attachment. The radiological finding of hypoplastic clavicles has been seen in trisomy 17 and $18 .{ }^{6}$ Microscopic renal cystic disease has been found in between 1 per 1000 and 5 per 100 paediatric necropsies, and is often associated with multiple malformations, most commonly oesophageal atresia or other anomalies of the gastrointestinal tract, or chromosomal abnormalities. ${ }^{7}$ Cortical cysts have been reported in association with trisomies 13,18 , and 21 , and Turner's syndrome. ${ }^{7}$ It is interesting to note the association here, as in other established genetic syndromes, of ear abnormalities with malformations of the urinary tract.

Each of the external features described in patients with $3 p$ - syndrome is seen in other chromosomal anomalies, most often in the better known syndromes involving alterations of chromosomes $4,5,13,14$, 15,18 , and 21 , as well as in patients damaged antenatally by drugs, infection, or other external causes. ${ }^{18}$ Consistent association of visceral anomalies with these characteristics cannot be evaluated on the basis of a single case. However, the constellation of growth and mental retardation, microcephaly, dolichocephaly, micrognathia, epicanthic folds, low set or malformed ears, ptosis, and postaxial polydactyly may constitute a recognisable clinical syndrome.

The authors are grateful to Dr Nancy Geneiser for radiographic consultation, Ms Barbara Preston for typing the manuscript, and $\mathrm{Mr}$ Martin Rotker for preparation of photographs.

\section{References \\ 1 Verjaal N, DeNef J. A patient with a partial deletion of the short arm of chromosome 3. Am J Dis Child 1978; 132:43-5. \\ 2 Gonzales J, Lesourd S, Braconnier A. Deletion partielle du bras court du chromosome 3. Ann Genet (Paris) 1980; 23:119-22. \\ 3 Merrild U, Berggreon S, Hansen L, Mikkelsen M, Henningsen K. Partial deletion of the short arm of chromosome 3. Eur J Pediatr 1981 ;135:211-6. \\ 4 Garcia Sagredo JM, Quintana Castilla A, Ludena Carpio MC. The phenotype of partial monosomy 3(p25 pter) observed in two unrelated patients. Abstracts of the Symposium of the European Society of Human Genetics, Zurich, 25-26 March 1981:69. \\ 5 Higginbottom MC, Mascarello JT, Hassin H, McCord WK. A second patient with partial deletion of the short arm of chromosome 3: karyotype 46,XY,del(3)(p25). $J$ Med Genet 1982;19:71-3. \\ 6 Warkany J. Congenital malformations. Notes and com- ments. Chicago: Year Book Medical Publishers, 1971. \\ 7 Mir S, Rapola J, Koskimies O. Renal cysts in pediatric autopsy material. Nephron 1983;33:189-95. \\ 8 Sorsby A, ed. Clinical genetics. 2nd ed. London: Butterworth, 1973.}

Correspondence and requests for reprints to $\mathrm{Dr}$ M Alba Greco, Department of Pathology, MSB 613, New York University Medical Center, 550 First Avenue, New York, NY 10016, USA.

\title{
Down's syndrome with a recombinant tandem duplication of chromosome 21 derived from a maternal ring
}

\author{
R T HOWELL, A McDERMOTT, ANNE GARDNER, \\ AND VALERIE DICKINSON \\ South Western Regional Cytogenetics Centre, Southmead Hospital, Bristol BS10 5NB.
}

SUMMARY An account is given of the cytogenetic investigations of a girl with Down's syndrome found to have a dicentric duplication of chromosome 21. This tandem type of rearrangement was interpreted as a recombinant derived from a single meiotic crossover between a maternal ring 21 and its normal homologie. A population of cells was also found in which breakage of the dicentric resulted in a chromosome 21 with a small terminal deletion. The mother and the proband's younger brother, who was also a ring 21 heterozygote, were both clinically nornal.

A high proportion of those who possess a ring chromosome manifest clinical abnormalities owing to the deletion of material from the ends of the affected chromosome, and possibly also to the 